Studia Oecumenica 17 (2017)

DOI: $10.25167 / \mathrm{SOe} / 17 / 2017 / 381-392$

StanistaW RABIEJ

Wydział Teologiczny UO

\title{
Ekumeniczny wymiar mariologii
}

\section{The Ecumenical Dimmension of Mariology}

\begin{abstract}
The paper analyzes contemporary trends in mariology. It briefly outlines the assumptions of the maximalist (christotypic) and minimalist (ecclesiotypic) mariology. By suggesting their complementarity the ecumenical model of mariology is proposed. His basis is systematically developed in many bilateral groups, e.g.: The Ecumenical Society of the Blessed Virgin Mary in England, The Anglican-Roman Catholic International Commission - ARCIC, The Lutheran-Catholic Commission in the USA and Germany, The Group of Dombes. Echoes of these arrangements have been reflected in the content of catechisms developed by local churches, e.g. in the Netherlands, Germany and France.
\end{abstract}

Keywords: mariology, ecumenical dialogue, ecclesiology.

\section{Streszczenie}

Artykuł podejmuje analizę współczesnych nurtów w mariologii. W zwięzły sposób zarysowuje założenia mariologii maksymalistycznej (chrystotypicznej) i minimalistycznej (eklezjotypicznej). Postulując ich komplementarność, proponuje model ekumeniczny mariologii, której podstawy są systematycznie wypracowywane w wielu grupach bilateralnych. Dla przykładu zaprezentowano owoce prac: Ekumenicznego Stowarzyszenia Błogosławionej Dziewicy Maryi w Anglii, Międzynarodowej Komisji Anglikańsko-Katolickiej, Komisji do Dialogu Luterańsko-Katolickiego w USA, Luterańsko-katolickiej grupy na terenie Niemiec, Grupy z Dombes. Echa tych uzgodnień znalazły swoje odzwierciedlenie w treści katechizmów wypracowywanych przez Kościoły lokalne, np. w Holandii, Niemczech czy Francji.

Słowa kluczowe: mariologia, dialog ekumeniczny, eklezjologia.

Mariologia stała się dosyć kontrowersyjnym traktatem teologii systematycznej. Już sam termin „mariologia” wzbudza pewne zastrzeżenia. Jeden z czołowych teologów francuskich doby obecnej, Bernard Sesboüé, proponuje, aby raczej stosować nazwę „teologia maryjna”. Uważa, że w ten sposób uniknie się 
izolacji tej ważnej części teologii dogmatycznej¹. Godząc się na to rozwiązanie, trzeba jednak zauważyć niebezpieczeństwo jego złego rozumienia. Można go bowiem pojmować jako supozycje teologii tworzonej przez Maryję, tak jak to jest w przypadku teologii Janowej czy Pawłowej. Tymczasem chodzi raczej o myśl teologiczną skupioną wokół Matki Jezusa Chrystusa, pozostającej w silnej więzi z Kościołem. Te dwa wymiary - chrystotypiczny i eklezjotypiczny - stanowią od stuleci o charakterze uprawianej mariologii. Pierwszy z nich wiąże osobę Maryi z Jezusem Chrystusem i opisuje Ją w ścisłej więzi z Jej Synem. Stąd określa się ten nurt jako „maksymalistyczny”, gdyż rola Maryi wzrasta w miarę odkrywania jej trwałych więzi z Chrystusem i Kościołem, jako Jego Matka. Natomiast drugi kierunek - eklezjotypiczny - odczytuje rolę Maryi w powiązaniu ze wspólnotą wyznawców Jezusa Chrystusa, gdzie osoba Jego Matki staje w szeregu członków Kościoła, jako „siostra we wierze”. Dlatego ten sposób patrzenia na Maryję jest określany jako „minimalistyczny”. Przez pryzmat tych dwóch zasadniczych kierunków uprawianej mariologii spróbujemy ocenić możliwość kształtowania jej wymiaru ekumenicznego ${ }^{2}$.

\section{Mariologia chrystotypiczna}

Ten typ mariologii „maksymalistycznej” zdaje się mieć swój najmocniejszy wyraz w orzeczeniach dogmatycznych oraz nauczaniu magisterium Kościoła rzymskokatolickiego w XIX i na początku XX stulecia. Przyjmuje się, że do tej pory proklamowano cztery dogmaty mariologiczne. Pierwszy z nich został ogłoszony w 431 r. przez Sobór w Efezie, który wprowadził grecki termin Theotokos na określenie „Tej, która porodziła Boga”. Od szóstego stulecia w Kościele zachodnim pojawiło się jego łacińskie thumaczenie: Mater Dei (Matka Boga) ${ }^{3}$. W ocenie niektórych teologów nie ma pewności co do charakteru dogmatycznego orzeczeń efeskich (431). Niektórzy uważają, że mamy do czynienia z „dogmatyzacją retrospektywną" albo owocem późniejszej interpretacji, usiłującej dokonać harmonizacji nurtu maksymalistycznego ${ }^{4}$.

Drugi dogmat, kojarzony z Synodem na Lateranie (649), dotyczy greckiego określenia Maryi jako Aei Parthenos, w tłumaczeniu łacińskim: Semper Virgo. I w tym wypadku pewne wątpliwości wzbudza zarówno charakter samego Synodu laterańskiego, jak i ranga jego wypowiedzi. Spotykamy opinię, że było to

\footnotetext{
${ }^{1}$ B. Sesboüé, Pour une théologie oecuménique, Paris 1990, 389.

${ }^{2}$ W. Beinert, H. Petri, Handbuch der Marienkunde, t. I, Regensburg 19962 298.

${ }^{3}$ K.E. Borresen, Marie dans la théologie catholique, ConcF 18 (1983), 95.

${ }^{4}$ D. Cerbelaud, Marie, un parcours dogmatique, Paris 2003, 93-95.
} 
raczej lokalne zgromadzenie biskupów ${ }^{5}$, które nie zamierzało wypracowywać orzeczeń dogmatycznych ${ }^{6}$. Niezależnie od przyznanej im rangi, oba orzeczenia magisterium Kościoła były niejako odpowiedzią na pojawiające się herezje chrystologiczne, źle interpretujące podwójną naturę Jezusa Chrystusa. Możemy więc mówić o paradoksalnej roli błędów dogmatycznych, które wręcz wymusiły precyzyjne orzeczenia Kościoła. W tym wypadku narzędziem „dogmatotwórczym” stała się mariologia. W obronie boskości Drugiej Osoby Trójcy Świętej odwołano się do roli i godności Maryi w historii zbawienia.

Inny rodowód posiadają pozostałe dwa dogmaty mariologiczne, które pojawiły się w XIX i XX stuleciu. Zarówno dogmat o Niepokalanym Poczęciu NMP (1854), jak i o jej Wniebowzięciu (1950), wypracowane w łonie Kościoła rzymskokatolickiego, zostały promulgowane autorytetem biskupa Rzymu - papieży Piusa IX i Piusa XII. Inspiracją dla tych orzeczeń było factum Ecclesiae, czyli wiara Ludu Bożego wypowiadająca się w pobożności i kulcie. Zdecydowanie mniej w tym przypadku szukano odniesień biblijnych i odwołań do pism ojców Kościoła pierwszych stuleci. W tych orzeczeniach można dopatrywać się mocniejszej koncentracji wokół osoby Maryi. Chrystologia nie jest tu już dominantą. Stąd też oba dogmaty mogą także współtworzyć nurt eklezjotypiczny (minimalistyczny) w mariologii.

Niemniej mariologia tworzona w łonie Kościoła rzymskokatolickiego przed Vaticanum II charakteryzuje się tendencją maksymalistyczną. Dostrzega się nadzwyczajną rolę Maryi w historii zbawienia. Ze względu na bliskość ze swoim Synem jest Ona ponad Kościołem, niejako na zewnątrz, w bezpośredniej bliskości majestatu Trójcy Świętej. Znajduje to swoje odzwierciedlenie zarówno w sprawowanym kulcie, jak i sztuce sakralnej. Wypowiada się w nich wiara i przekonania wiernych oddających cześć Matce Zbawiciela. Próbuje się tworzyć nowe tytuły maryjne. Na szczególną uwagę zasługują dwa z nich: „Pośredniczka” i „Współodkupicielka”. Podkreśla się przez nie szczególną rolę Maryi w dziele zbawienia ${ }^{7}$. Próby ich upowszechnienia czy wręcz „zdogmatyzowania” nie miały bezpośredniego przełożenia zarówno w pismach teologów, jak i orzeczeniach UNK. Stają się raczej osnową dyskusji teologicznych, wymierzonych przeciw tendencjom maksymalistycznym w mariologii. W tej debacie krzepnie drugi nurt: minimalistyczny.

Szczególnym czasem i miejscem konfrontacji dwóch kierunków mariologicznych był Sobór Watykański II. Wśród jego dokumentów jest m.in. Konstytucja dogmatyczna o Kościele Lumen gentium, gdzie rozdział ósmy jest poświęcony

5 Taki status Synodu laterańskiego z 649 r. uznają m.in. W. Beinert, H. Petri, Handbuch der Marienkunde, Regensburg 1984ㄴ, 270.

${ }^{6}$ Tego rodzaje opinię głosi przedstawiciel mariologii maksymalistycznej M. O’CARROLL, Glory of Mary, Santa Barbara (b.r.w.), 3.

${ }^{7}$ M.-J. BÉRÉRE, Marie. Tout simplement, Paris 1999, 143. 
Maryi ${ }^{8}$. W tekście promulgowanym 21 listopada 1964 r. znajdujemy owoc intensywnej dyskusji ojców i ekspertów soboru. Żaden z pozostałych tekstów Vaticanum II nie miał tak wielu komentarzy i głosów w ramach intensywnej dyskusji teologicznej9.

K. Rahner - jako ekspert soborowy - zauważa nawet jej nieproporcjonalną długość (unproportioneller Länge) ${ }^{10}$. Podczas gdy inny z ekspertów, R. Laurentin, był wręcz zachwycony jej intensywnością $\mathrm{w}$ relatywnie długim czasie ${ }^{11}$. W rezultacie ósmy rozdział Lumen gentium zawiera naprzemienną obecność wspomnianych wyżej nurtów mariologicznych. Już we Wprowadzeniu (52-54) pojawiają się zarówno akcenty chrystotypiczne, jak i eklezjotypiczne. Wskazują na to robocze podtytuły: De Beata Virgine in mysterio Christi (52), Beata Virgine et Ecclesiae (53) ${ }^{12}$. Podobnie jest w części zatytułowanej: De munere Beata Virgine in oeconomia salutis (55-59), która odsłania fundamenty staro- i nowotestamentalne dla tytułu Matka Jezusa ${ }^{13}$. W całościowym spojrzeniu na Stary i Nowy Testament cytowane teksty uzasadniają miejsce Maryi w mesjanistycznych zapowiedziach przyjścia na ziemię Jezusa, w Jego poczęciu i narodzeniu, ziemskim życiu oraz misji nauczania, aż po śmierć i zmartwychwstanie. Jednocześnie pokazana jest rola Matki Jezusa w gronie pierwszej wspólnoty chrześcijan po zmartwychwstaniu i wniebowstąpieniu jej Syna. W trzecim paragrafie VIII rozdziału (60-65): De Beata Virgine et Ecclesia pojawiają się wyraźne akcenty chrystologiczne i soteriologiczne. Podkreślona jest nadrzędna rola Chrystusa w ekonomii zbawienia i łaski. Rola Maryi w i dla Kościoła wynika z Jej nadzwyczajnego związku z swoim Synem. Jako Matka i Dziewica pozostaje wzorem w porządku wiary i miłości, służby i misji powierzonej wspólnocie wyznawców Jezusa Chrystusa. Wysiłek godzenia obu aspektów mariologii znajduje jeszcze swoje potwierdzenie w końcowych fragmentach Lumen gentium: De Cultu Beatae Virginis in Ecclesia (66-67); Maria, signum certae spei et solatii peregrinanti populo Dei (68-69). Ojcowie soborowi podkreślają charakter chrystocentryczny kultu maryjnego w Kościele, gdzie Matka Chrystusa stanowi znak nadziei dla wspólnoty chrześcijan i żyjących poza nią.

W sumie dosyć kompleksowe ujęcie mariologii w tym ważnym dokumencie Soboru Watykańskiego II znalazło wielorakie zrozumienie w dobie posoboro-

8 KK 52-69

9 G. PhiliPs, L'Église et son mystère au II concile du Vaticane, t. II, Paris 1968, 207.

${ }^{10}$ K. Rahner, H. Vorgrimler, Konzilskompendium, Freiburg im Br. 1968, 121.

11 R. Laurentin, La Vierge au Concile, Paris 1965, 8-50.

12 Prezentowane podtytuły nie zostały zamieszczone w ostatecznej wersji Konstytucji dogmatycznej o Kościele. Pochodzą z tzw. textus emendatus.

${ }^{13}$ KK 55: „Pismo święte Starego i Nowego Testamentu oraz czcigodna Tradycja coraz jaśniej przedstawiają i niejako naocznie ukazują rolę Matki Zbawiciela w ekonomii zbawienia". 
wej. Najogólniej można dostrzec pięć sposobów interpretacji ósmego rozdziału Konstytucji. Pierwsza grupa teologów dopatruje się wyraźnej przewagi mariologii eklezjotypicznej. Np. Flamandowie: Edward Schillebeecks i Ernest Henau, odczytują nauczanie Vaticanum II jako zachętę do podkreślenia roli Maryi bardziej we wspólnocie wierzących niż u boku Chrystusa. Kwestionując jej funkcję aktywną w obiektywnym zbawieniu, widzą w niej model Kościoła ${ }^{14}$. Druga grupa interpretatorów jest proweniencji protestanckiej. Podzielając pogląd teologów flamandzkich, dodają, że zwycięski nurt eklezjotypiczny nie tyle deprecjonuje kierunek chrystotypiczny, ile raczej wskazuje na rolę Kościoła w porządku zbawienia i łaski (w soteriologii i charytologii) ${ }^{15}$. Trzecia grupa komentatorów tekstu soborowego zauważa w nim pozytywną syntezę obu nurtów mariologicznych, czy wręcz rekoncyliację dwóch komplementarnych ujęć ${ }^{16}$. Odmienny pogląd wyraża czwarta grupa, która woli mówić o kompromisie między dwoma nurtami. Godnym podkreślenia jest fakt obecności mariologii w Konstytucji dogmatycznej o Kościele, gdzie rozdział typowo chrystocentryczny uwzględnia rolę Maryi w Kościele ${ }^{17}$. Pojawia się też piąta grupa, tzw. neo-maksymalistów, którzy uważają, że Sobór w nauczaniu mariologicznym za mocno przychylił się w stronę teologii protestanckiej ${ }^{18}$. Jakkolwiek oceniać myśl mariologiczną zawartą w Lumen gentium VIII, warto zauważyć, że w późniejszym nauczaniu UNK dosyć wyraźnie uwyraźni się wola przełamywania linii demarkacyjnej między dwoma sposobami uprawiania mariologii. Chociaż wielu teologom ciągle wydawać się będzie, że zwłaszcza papieże XX stulecia optują w stronę mariologii eklezjotypicznej ${ }^{19}$.

\section{Mariologia eklezjotypiczna}

Kierunek minimalistyczny $\mathrm{w}$ mariologii znajduje swoich przedstawicieli wśród teologów zorientowanych ekumenicznie. Poszukują oni źródeł dla swojej refleksji w tekstach biblijnych i patrystycznych. Pozwalają one dostrzec rolę Ma-

${ }^{14}$ E. Schillebeecks, Mariologie, w: E. Schillebeecks, C. Halkes (red.), Maria, Gisteren, vandaag, morgen, Baarn 1992, 30-31; E. Henau, Hemelse Koningen, w: G. Danneels, E. Henau (red.), Maria en de Nieuve evangelisatie, Averbode - Apeldoorn 1988, 42.

${ }^{15}$ K. Riesenhuber, Maria in theologischen Verständnis von Karl Barth und Karl Rahner, Freiburg im Br. 1973, 28; Groupe Des Dombes, Marie dans le dessein de Dieu et la Communion des saints, Paris 1999, 109-110.

16 W. BeINERT (red.), Glaubenszugänge. Lehrbuch der Katholischen Dogmatik, t. II, Paderborn 1995,310 .

${ }^{17}$ K. E. Børresen, Marie, ConcF 188 (1983), 102.

${ }_{18}$ M. O'CARrol, The Glory of Mary, $14 \mathrm{n}$.

${ }_{19}$ Typowym argumentem w tym przypadku jest tytuł Mater Ecclesiae nadany Maryi w przemówieniu promulgacyjnym dla Konstytucji Lumen gentium przez Pawła VI. 
ryi we wspólnocie Kościoła wierzących. Zwolennicy tego nurtu, jeszcze długo przed Vaticanum II, proponowali powrót do fundamentalnych zasad mariologii ${ }^{20}$. Wśród nich warto zauważyć określenie Maryi jako: model Kościoła (O. Semmelroth), doskonała przedstawicielka ludzkości (H.M. Köster), korona stworzenia (K. Rahner, M. Schmaus), Matka zbawienia (E. Schillebeeckx). Te oraz jeszcze inne tytuły maryjne nie kwestionują Jej bliskości z Chrystusem. Nawiązując do źródeł skrypturystycznych, myśli patrystycznej (Ireneusz z Lyonu, Ambroży), pozwalają na ponowne odkrycie Jej związku ze wspólnotą wyznawców Jezusa Chrystusa. Biblijne źródła dla tych koncepcji mariologicznych dosyć kompleksowo omawia M. Thurian - teolog protestancki, a zarazem członek wspólnoty ekumenicznej w Taizé21.

Dosyć nieoczekiwanym wsparciem dla tendencji minimalistycznych w mariologii stały się pierwsze międzynarodowe kongresy mariologiczne organizowane pod egidą Piusa XII. Już ich hasła przewodnie wskazują na chrystotypiczność proponowanych treści. Pierwszy z nich, zatytułowany Alma Socia Christi, odbył się w 1950 r.; następny - Virgo Immaculata - w 1952 r., a trzeci z kolei: Mater et Ecclesia - w 1954 r. Każdy z kongresów w pewien sposób przygotowywał idee, które znalazły swoje uwieńczenie w ósmym rozdziale $\mathrm{Lu}$ men gentium $^{22}$.

Czas bezpośredni po soborze jeszcze nie obfitował nadmiarem refleksji teologicznych skupionych wokół Matki Jezusa. Pewnym impulsem byli papieże tej epoki, odznaczający się osobistą pobożnością maryjną. Najpierw Paweł VI promulgujący dokumenty soborowe dopełnił je dwoma adhortacjami apostolskimi: Signum magnum ${ }^{23}$ oraz Marialis cultus ${ }^{24}$. Pierwszy z tych dokumentów nie znalazł szerokiego oddźwięku w komentarzach teologicznych. W nielicznych zauważono, że tekst zawiera wiele nostalgii za porzuconym maksymalizmem mariologicznym. Mimo że Paweł VI odwołuje się do tytułu Matka Kościoła, podkreśla, że liturgia i związany z nią kult są niezbywalnymi źródłami dla mariologii. W zakończeniu zachęca do odnowienia osobistego oddania się Sercu Niepokalanej Maryi, tak jak wcześniej (1942) zrobił to Pius XII.

Druga adhortacja-Marialis cultus - bardziej szczegółowo zarysowuje zasady poprawnego kultu maryjnego. Można w tym tekście dostrzec pewną formę dyrektorium, które dopełnia treści Lumen gentium VIII. W początkowym fragmen-

${ }^{20}$ K. RAHNER, Le principe fondamental de la théologie mariale, RSR, t. XL/II, Paris 1954, 508-509.

${ }^{21}$ M. Thurian, Marie, Mère du Seigneur, figure de l'Église, Taizé 1963.

22 A. Stacpoole, Mary's place in Christian Dialogue, Slough 1982, 8.

${ }^{23}$ Tekst w wersji łacińskiej i włoskiej ukazał się 13 maja 1967 r. w „L'Osservatore Romano”. Później w thum. franc.: „Documentation catholique” (1967) 1495, 961-972.

24 „Documentation catholique” (1974) 1651, 301-321. 
cie adhortacji (1-24) znajdujemy uzasadnienie roli Maryi w odnowionej liturgii rzymskiej. Natomiast druga część (29-37) wskazuje na konkretne, cztery rysy właściwej pobożności maryjnej. Papież przypomina, że winna ona: być osadzona na źródłach biblijnych ${ }^{25}$, praktykowana $\mathrm{w}$ ramach liturgii oraz nosić rysy antropologiczne i ekumeniczne. Piąty wymiar - chrystologiczny - został zauważony przy omawianiu klasycznych modlitw maryjnych: Anioł Pański oraz różańca. Wyraźnym rysem eklezjotypicznym tej adhortacji są obecne w niej tytuły: Matka Kościoła oraz Siostra wszystkich wierzących ${ }^{26}$.

Pontyfikat Jana Pawła II był zaznaczony głębokim pietyzmem maryjnym. Jego wyrazem jest m.in. encyklika Redemptoris Mater ${ }^{27}$. Jej centralnym przesłaniem jest wskazanie na wiarę Maryi, dzięki której jako Matka Boga staje w centrum Kościoła pielgrzymującego. Myśl ta jest wyraźnym echem soborowej idei „pielgrzymki w wierze”, która pojawia się wielokrotnie w Lumen gentium ${ }^{28}$. Jan Paweł II nadał jej charakter uniwersalny i zarazem bardzo znaczący ${ }^{29}$.

W ocenie myśli mariologicznej obu papieży zauważa się też pewne różnice. W sposób widoczny zarysowują się one w interpretacji tytułu „Pośredniczki”. Paweł VI, podobnie jak Vaticanum II, unikają wyraźnego stosowania tego określenia. Dyktowane jest to względami dialogu ekumenicznego, gdzie rolę pośrednika rezerwuje się jedynie dla osoby Jezusa Chrystusa (1 Tm 2,5). Tymczasem w Redemptoris Mater pojawia się wyraźna wzmianka o pośrednictwie Maryi. W najdłuższym tekście XX stulecia na temat pośrednictwa Maryi Jan Paweł II wskazuje, że jest ono zakorzenione w Chrystusowym ${ }^{30}$. Papież podkreśla, że Maryja pośredniczy jako Matka; Jej pośrednictwo ma charakter wstawienniczy, tj. modlitewny, błagalny, i nie umniejsza jedynego pośrednictwa Jezusa, ponieważ jest od Niego całkowicie zależne, ukazuje Jego moc, gdyż Jezus Chrystus jest jedynym pośrednikiem między Bogiem a ludźmi (por. 1 Tm 2,5-6). Od tego jedynego pośrednictwa całkowicie jest zależne pośrednictwo Maryi. W ocenie niektórych teologów, taki sposób opi-

${ }^{25}$ Pawet VI, Adhortacja Marialis cultus, 30: „Kult Najświętszej Maryi Panny żadną miarą nie może oddalać się od tego ogólnego ukierunkowania (tj. biblijnego) życia chrześcijańskiego; co więcej, głównie z niego powinien czerpać nowe siły i niezawodną pomoc. Pismo Swięte bowiem, odsłaniając w niezwykły sposób Boży plan zbawienia ludzkiego, wszędzie przepojone jest tajemnicą Zbawiciela i wskazuje bardzo wyraźnie na Tę, która była Matką i Towarzyszką tegoż Zbawiciela".

${ }^{26}$ E. Schillebeecks, C. Halkes, Maria, 37-38.

27 JAN PAWE⿺ II, Encyklika Redemptoris Mater (25 III 1987), AAS 79 (1987), 382n.

${ }^{28}$ KK 5, 6, 25, 28, 30, 31.

29 W. Beinert, H. Petri, Handbuch der Marienkunde, 328-329.

${ }^{30}$ Komentując prośbę Maryi w Kanie, Jan Paweł II podkreśla: „Maryja staje pomiędzy Synem a ludźmi w sytuacji ich braków, niedostatków i cierpień. Staje «pomiędzy», czyli pośredniczy, nie jako obca, lecz ze stanowiska Matki, świadoma, że jako Matka może - lub nawet więcej: «ma prawo» - powiedzieć Synowi o potrzebach ludzi. Jej pośrednictwo ma więc charakter wstawienniczy: Maryja «wstawia się» za ludźmi» (RM 21). 
su roli Matki Jezusa wymaga wiele wyjaśnień i uzasadnień, aby być dobrze pojmowanym ${ }^{31}$.

W sumie warto zauważyć, że znaczące teksty mariologiczne obu papieży wpisują się w myśl mariologiczną Soboru Watykańskiego II, która jest eklezjotypiczna i niemaksymalistyczna ${ }^{32}$. Proponowane tytuły mariologiczne mają mocne uzasadnienie biblijno-patrystyczne. Całość cechuje także duża troska ekumeniczna.

\section{Mariologia ekumeniczna}

Wymiar ekumeniczny w mariologii dojrzewał przez stulecia. Jednak dopiero $\mathrm{w}$ epoce posoborowej pojawiły się rozwiązania, które zaowocowały oficjalnymi deklaracjami, tekstami zgody, szczególnie w relacji katolicko-protestanckiej. W gronie reformowanych pojawili się teolodzy, którzy nie do końca byli zgodni z wcześniejszymi koncepcjami autorstwa np. K. Bartha czy E. Thumeysena ${ }^{33}$. W 1969 r. katolicy i protestanci w Anglii zainicjowali Ekumeniczne Stowarzyszenie Błogosławionej Dziewicy Maryi (The Ecumenical Society of the Blessed Virgin Mary), które skupiło swą refleksję wokół osoby Matki Jezusa. Obie strony chętnie zauważały elementy wspólne, łączące obie wizje mariologiczne, ale też nie pomijały różnic na tym polu ${ }^{34}$. Po siedmioletnim okresie dialogu skoncentrowanego wokół roli Chrystusa, Jego Matki i świętych w procesie zbawienia, wypracowano dokument: Miejsce Maryi $w$ dialogu chrześcijańskim ${ }^{35}$. Wspólne uzgodnienia zostały ujęte $\mathrm{w}$ dwóch podstawowych rozdziałach: Zadania $i$ perspektywy; Biblijne $i$ historyczne podstawy. W konkluzji stwierdzono, że nie sposób być wierny tekstom biblijnym pomijając osobę Maryi.

W 1992 r. Komisja do Dialogu Luterańsko-Katolickiego na terenie USA opublikowała wspólny tekst: Jeden Pośrednik, święci i Maria, odsłaniający punkty zbieżne i rozbieżności tych dwóch tradycji ${ }^{36}$. Dotyczą one zasadniczo roli Maryi i świętych w Kościele. Przedstawione wnioski pokazują, że mimo różnic

31 B. SesboüÉ, Pour une théologie øecuménique, 397-398; E. SchillebeEcks, C. Halkes (red.), Maria, 37-38.

32 S.C. Napiórkowski, O mariologii eklezjotypicznej, w: J. GaJeK, K. Peк (red.), Matka Jezusa pośród pielgrzymującego Kościoła, Warszawa 1993, 19-36; B. ForTe, Maryja, Ikona Tajemnicy, Warszawa 1999, 217-225.

33 W. TAPpolet, Das Marienlob der Reformatoren, Tübingen 1962.

34 J. MacQuarrie, Mary for all Christians, Edinbourgh $2001^{2}$.

35 A. Stacpoole (red.), Mary's Place in Christian Dialogue, Slough 1982

${ }^{36}$ H.G. Anderson, J.F. Stafford, J. Burgess (red.), The One Mediator, the Saints and Mary. Lutherans and Catholics in Dialogue VIII, Minneapolis - Augsburg 1992. 
w pojmowaniu zbawczej roli Maryi, sposobów wzywania wstawiennictwa Matki Jezusa oraz treści dwóch późniejszych dogmatów, nie ma podstaw do mówienia o znaczących różnicach (ang. church-dividing) w mariologii ${ }^{37}$.

W ślad za osiągnięciami komisji amerykańskiej poszła, pięć lat później, tzw. Grupa z Dombes, proponując drogę nawrócenia Kościołów zaangażowanych w dialog ekumeniczny ${ }^{38}$. Wobec katolików proponuje się odejście od koncepcji maksymalistycznych poprzez usytuowanie dwóch ostatnich dogmatów mariologicznych w odpowiedniej hierarchii prawd wiary ${ }^{39}$ oraz ukształtowania kultu maryjnego w duchu wskazań adhortacji Marialis cultus. Natomiast od strony luterańskiej domagano się, w imię nawrócenia, przyznania Maryi odpowiedniego miejsca w wspólnocie wierzących, jako współpracującej dla zbawienia innych poprzez swoje aktywne zaangażowanie. Proponuje się też luteranom szersze wprowadzenie osoby Maryi do liturgii ${ }^{40}$.

Do podobnych wniosków doszła luterańsko-katolicka grupa na terenie Niemiec, która opublikowała uzgodnienie pod znamiennym tytułem: Kościót jako wspólnota świętych ${ }^{41}$. Analogicznie uczyniła Międzynarodowa Komisja Anglikańsko-katolicka (The Anglican-Roman Catholic International Commission ARCIC), która skupiała teologów anglojęzycznych ${ }^{42}$. W obu wypadkach znajdujemy znamiona mariologii eklezjotypicznej, gdzie osoba Maryi jest postrzegana we wspólnocie wyznawców Jezusa Chrystusa, obdarzonych łaską wiary i nadziei. Przedstawione argumenty teologiczne, wyrastające ze źródeł skrypturystycznych, odzwierciedlają wcześniejsze pracy Grupy z Dombes.

Owoce dialogu ekumenicznego w obszarze mariologii znalazły swe odzwierciedlenia w nauczaniu i praktyce Kościołów zaangażowanych w proces zbliżania stanowisk na polu mariologii. Po tronie katolickiej dobrze ilustrują to katechizmy wypracowane przez samodzielne konferencje episkopatów w krajach, gdzie budowanie poprawnych relacji ekumenicznych ma swoją dobrą tradycję. Tak się stało w Holandii. Jeszcze w 1966 r. został opublikowany Katechizm, w którym przedstawia się Matkę Jezusa w kontekście chrystologicznym, soteriologicznym i eschatologicznym. W kontekście kluczowych wydarzeń biblijnych (Wciele-

${ }^{37}$ P. JASKóŁA, Ku jedności $w$ Chrystusie. Wybrane zagadnienia z problematyki ekumenicznej i dogmatycznej, Opole 2016, 89-98.

${ }^{38}$ Dwa wcześniejsze dokumenty Grupy z Dombes (1996/1997) zostały opublikowane we wspólnym wydaniu: Marie dans le dessein de Dieu et la communion des saints, Paris 1999.

${ }^{39}$ Podobne postulaty formułowali niektórzy teolodzy zaangażowani w dialog ekumeniczny: H. KüNG, Christ sein, München 1974; W. BEINERT (red.), Glaubenszugänge, 358.

40 J. Freitag, Maria in Gottes Heilsplan und in der Gemeinschaft der Heiligen, Cath (2001) 1, 29-51.

${ }^{41}$ Bilaterale Arbeitsgruppe der Deutschen Bischofskonferenz und der Kirchenleitung der Vereinigten Evangelisch-lutherischen Kirche Deutschlands, Communio Sanctorum. Die Kirche als Gemeinschaft der Heiligen, Paderborn - Frankfurt am M. 2000.

${ }^{42}$ ARCIC, Mary, Grace and Hope in Christ, London - New York 2005. 
nie, dzieciństwo Jezusa, cud w Kanie, ukrzyżowanie, Zesłanie Ducha Świętego) pojawiły się również odniesienia mariologii do eklezjologii i charytologii. Zaś dogmaty o Niepokalanym Poczęciu i Wniebowzięciu starano się umieścić w odpowiedniej hierarchii prawd wiary. W tym wypadku był to artykuł wiary: Communicatio sanctorum ${ }^{43}$.

Podobnego wysiłku dokonała Konferencja Episkopatu Niemiec w swoim Katechizmie dla dorosłych ${ }^{44}$. Mariologii poświęcono cały jeden rozdział ${ }^{45}$. W czterech częściach omówiono: miejsce Maryi w Ewangelii (s. 166-170); macierzyństwo (s. 170-173); dziewictwo (s. 174-178); błogosławieństwo i chwała (s. 178-182). W swej treści Katechizm odzwierciedla nauczanie Vaticanum II. Cały wysiłek jest położony na sposobie wyjaśnienia roli Matki Jezusa w historii zbawienia z uwzględnieniem problemów egzegetycznych i ekumenicznych, szczególnie w dialogu z luteranami. Wrażliwość tego typu jest zapewne rezultatem bezpośredniego styku obu Kościołów na terenie Niemiec.

Kilka miesięcy później Konferencja Episkopatu Francji zadeklarowała wolę redakcji swojego katechizmu. Stało się to faktem w $1991 \mathrm{r} .{ }^{46}$ Również w tym wypadku mariologia została zamieszczona w części eklezjologicznej ${ }^{47}$. Eksponując wiarę Maryi przedstawiono chronologiczny rozwój definicji dogmatycznych w mariologii. Odnosząc się bezpośrednio do wybranych fragmentów Lumen gentium, nakreślono Jej udział w historii zbawienia oraz więzi ze wspólnotą Kościoła. W porównaniu z poprzednio omawianymi katechizmami, wersja francuska ma charakter bardziej doktrynalny niż eksplikatywny.

W podobny sposób zredagowano Katechizm Kościoła Katolickiego (1992). W tym wypadku mariologii poświęcono relatywnie dużą partię tekstu. Punktem wyjścia stała się tajemnica Wcielenia. Pozwoliło to na omówienie dogmatów: o Niepokalanym Poczęciu, Theotokos i dziewictwie Maryi (§ 484-511). Natomiast na kanwie eklezjologii wyjaśniono dogmat o Wniebowzięciu (§ 963-975). Pewnym novum jest wnikliwe przedstawienie relacji Duch Święty - Maryja $(\S 721-726)^{48}$. Oficjalna wykładnia nauczania o roli i miejscu Maryi w Kościele nie ma tendencji maksymalistycznych. Raczej można zauważyć wysiłek pozytywnej recepcji treści Lumen gentium VIII. Nie proponuje się nowych tytułów

${ }^{43}$ De Bisschoppen van Nederland, De Nieuve Katechismus, Hilversum - Antwerpen 1966.

44 Die Deutsche Bischofskonferenz, Katholischer Erwachsenenkatechismus, t. I: Das Glaubensbekenntnis der Kirche, Kevelar 1985.

45 Tami̇e, 166-182. 1991.

${ }^{46}$ Les EvêQues de France, Catéchisme pour adultes. L'alliance de Dieu avec les hommes, Paris

47 Tamże, § 343-356.

48 T.D. ŁUKASZUK, Maryja - błogosławiona, która uwierzyła - wedtug Katechizmu Kościoła Katolickiego, w: S.C. NaPIÓRKowski, B. Kochaniewicz (red.), Maryja w Katechizmie Kościoła Katolickiego, Kraków 1996, 69-74. 
mariologicznych, ani skrajnie chrystotypicznej wersji mariologii. Tym sposobem dokumenty wypracowane zarówno przez oficjalne dykasterie watykańskie, jak i Kościoły lokalne odzwierciedlają ekumeniczną wrażliwość na tym polu i nie zamykają drogi dialogu z innymi wspólnotami chrześcijańskimi, którym osoba Maryi jawi się jako Matka wyznawców Jezusa Chrystusa.

\section{Podsumowanie}

Wbrew obawom wielu, w dobie posoborowej mariologia może pretendować do traktatu teologicznego o charakterze ekumenicznym. Uwzględniając komplementarne założenia mariologii chrystopicznej i eklezjotypicznej, wokół Matki Jezusa Chrystusa mogą spotkać się zarówno ci, którzy dostrzegają Jej miejsce w historii zbawienia na miarę wskazań tekstów biblijnych, jak i ci, którzy szukają w przestrzeni soteriologicznej Jej współdziałania ze swoim Synem. Dla Jego wyznawców pozostaje zawsze jako wzór wiernej służebnicy, wsłuchanej w Boże Słowo, i zatroskanej o los tych, którzy próbują odnaleźć się w gronie Jego uczniów.

\section{Bibliografia}

Anderson H.G., Stafford J.F., Burgess J. (red.), The One Mediator, the Saints and Mary. Lutherans and Catholics in Dialogue VIII, Minneapolis - Augsburg 1992.

ARCIC, Mary, Grace and Hope in Christ, London - New York 2005.

BeIneRT W. (red.), Glaubenszugänge. Lehrbuch der Katholischen Dogmatik, t. II, Paderborn 1995.

Beinert W., Petri H., Handbuch der Marienkunde, t. I, Regensburg $1996^{2}$.

Bérére M.-J., Marie. Tout simplement, Paris 1999.

Bilaterale Arbeitsgruppe der Deutschen Bischofskonferenz und der KirchenLeitung der Vereinigten Evangelisch-lutherischen Kirche Deutschlands, Communio Sanctorum. Die Kirche als Gemeinschaft der Heiligen, Paderborn - Frankfurt am M. 2000.

Cerbelaud D., Marie, un parcours dogmatique, Paris 2003.

Danneels G., Henau H. (red.), Maria en de Nieuve evangelisatie, Averbode Apeldoorn 1988.

De Bisschoppen van Nederland, De Nieuve Katechismus, Hilversum - Antwerpen 1966. 
Die Deutsche Bischofskonferenz, Katholischer Erwachsenenkatechismus, t. I: Das Glaubensbekenntnis der Kirche, Kevelar 1985.

Forte B., Maryja, Ikona Tajemnicy, thum. B. Widła, Warszawa 1999.

Freitag J., Maria in Gottes Heilsplan und in der Gemeinschaft der Heiligen, "Catholica” (2001) 1, s. 29-51.

GajeK J., Peк K. (red.), Matka Jezusa pośród pielgrzymującego Kościoła, Warszawa 1993.

Groupe des Dombes, Marie dans le dessein de Dieu et la Communion des saints, Paris 1999.

JASKÓŁA P., Ku jedności w Chrystusie. Wybrane zagadnienia z problematyki ekumenicznej i dogmatycznej (Ekumenizm i Integracja 31), Opole 2016, s. 89-98.

KüNG H., Christ sein, München 1974.

Laurentin R., La Vierge au Concile, Paris 1965.

Les EvêQues de France, Catéchisme pour adultes. L'alliance de Dieu avec les hommes, Paris 1991.

Macquarrie J., Mary for all Christians, Edinbourgh 2001².

PhiLIPs G., L'Église et son mystère au II ${ }^{e}$ concile du Vaticane, t. II, Paris 1968.

Rahner K., Vorgrimler H., Konzilskompendium, Freiburg im Br. 1968.

RIESENHUBer K., Maria in theologischen Verständnis von Karl Barth und Karl

Rahner, Freiburg im Br. 1973.

Schillebeecks E., Halkes C., Maria, Gisteren, vandaag, morgen, Baarn 1992.

SesboüÉ B., Pour une théologie oecuménique, Paris 1990.

Stacpoole A. (red.), Mary's Place in Christian Dialogue, Slough 1982

Tappolet W., Das Marienlob der Reformatoren, Tübingen 1962.

Thurian M., Marie, Mère du Seigneur, figure de l'Église, Taizé 1963. 